\title{
Mapping forest transition trends in Okomu reserve using Landsat and UK-DMC-2 satellite data
}

\author{
Alex Okiemute Onojeghuo $^{1,3}$, Ajoke Ruth Onojeghuo ${ }^{2,3}$ \\ ${ }^{1}$ Lancaster Environment Centre, Lancaster University, Lancaster, LA1 4YQ, United \\ Kingdom, lexisgis@yahoo.com \\ ${ }^{2}$ Centre of Landscape and Climate Research, University of Leicester, LE1 7RH, United \\ Kingdom, aroo1@ leicester.ac.uk \\ ${ }^{3}$ Department of Surveying and Geoinformatics, Nnamdi Azikiwe University, Awka, \\ Anambra State, Nigeria.
}

DOI: http://dx.doi.org/10.4314/sajg.v4i4.9

\begin{abstract}
This study aims to assess and quantify forest transition within and around one of the few remaining forest protected landscapes in south west Nigeria, Okomu forest reserve. The study utilised multi-temporal Landsat and UK-DMC-2 satellite images over three epochs (1987, 1999 and 2011) to assess forest landscape change over the study area. The unsupervised Iterative Self Organising Data Analysis technique was used to generate forest maps and subsequently used for forest change detection over two periods (1987 - 1999 and 1999 2011). From the results generated we were able to determine the effectiveness level of forest protected status assigned the study area as a means of reducing deforestation from 1987 to 2011. To achieve this objective, trends of forest change within and around the reserve were investigated. These result showed that forest protected status assigned to the reserve has not fully mitigated the effects of deforestation within and around the reserve. The annual deforestation rates of the reserve increased from 3.5\% in period 1 (1987-1999) to $5.1 \%$ in period 2 (1999-2011). We suggest that government needs to review forest policies and laws and improve upon the technical capacity of forest managers to improve forest management. Overall, the study has demonstrated the usefulness of using remote sensing and geographic information system to better understand dynamics of forest cover transition in forest protected areas across tropical forests.
\end{abstract}

\section{Introduction}

Over time, intense human activities such as: large-scale illegal logging, industrialisation, expansion of large rubber and oil-palm plantations within the reserve, uncontrolled hunting, and rise in human population have led to massive destruction of forest cover and the unique wildlife of Okomu Forest Reserve (OFR) (Ajayi, 2011, White and Oates, 1999). OFR was legally assigned its forest protection status in 1912 by Government Order 397 and in 1970, came under the management of the State Government, who acted on-behalf of the local 
community (Ajayi, 2011). However, following surveys aimed at evaluating conservation status in south western Nigeria (Anadu et al., 1988), the establishment of the now Okomu National Park (ONP) was setup within the core of the reserve owing to immense pressure from high rates of exploitation and human settlement expansion on its periphery. The sole purpose of the national park was to promote the protection of existing endangered wildlife within the reserve. The ONP is an important refuge for several threatened species, including the white-throated monkey (Cercopithecus erythrogaster), a major source of animal protein consumed by people living in the surrounding peripheral communities and sold commercially (Oates, 1995, Ajayi, 2011). Other endangered wildlife species of local and global concern within this protected area (PA) include: the forest elephant (Loxodonta africana cyclotis), chimpanzee (Pan Troglodytes), leopard (Panthera pardus) and Red-capped Mangabey (Cercocebus torquatus) (Ajayi, 2011). A total of 150 bird species in the Okomu National Park are classed as globally threatened (A1) or biome-restricted (A3) species respectively under the global Important Bird Area (IBA) criteria (BirdLife International, 2011a). Some examples of endangered bird species are the Forest Francolin (Francolinus lathami), Chestnut-flanked (Sparrowhawk Accipiter castanilius), and Long-tailed Hawk (Urotriorchis macrourus). Though classed as primary forest (Richards, 1939), the reserve is dominated by tree species characteristic of mature secondary vegetation (Jones, 1955). Examples of the African mahogany family (Meliaceae) found in the reserve are Khaya ivorensis, Entandrophragma angolense, Entandophragma cylindricum, Guarea cedrata, Guarea thompsonii and Lovoa trichilioides. Other economically important species include Milicia excelsa, Gossweilerodendron balsamiferum, Terminalia ivorensis, Terminalia superba and Triplochiton scleroxylon. The ecological value of this forest protected area (PA), which serves as an ideal habitat for endangered species has necessitated the need to investigate pattern of forest transition and levels of effectiveness in its forest protected status as a means to combating deforestation. Reports and studies indicate that the OFR is under immense pressure from large scale illegal logging, rapid expansion of oil palm plantations and incursion of a growing human population (Anadu et al., 1988, Eguavoen, 2007, Osehobo, 2013). However, sufficient scientific research aimed at estimating the actual level of disturbance to this threaten forest reserve is currently lacking. Such information would serve as a valuable resource to both federal and state government and other stakeholders charged with the responsibility of managing this fragile forest ecosystem, one of the very few forest PA in south west Nigeria.

Essentially, forest PAs are created to conserve forest biodiversity value from damaging processes such as deforestation (Clark et al., 2008). Due to increase in the annual rate of human population in Edo state, the demand for meat has risen thus resulting in uncontrolled hunting of wildlife within forest reserves (Oates, 1995). These products are mostly sold to city dwellers rather than being consumed locally (Anadu et al., 1988) and this negatively 
impacts on wildlife conservation in the forest reserve. There is need to quantify the spatial extent of forest transitional changes from subsistence pressures (natural and anthropogenic such as bush burning, illegal logging, hunting, indiscriminate faming, over harvesting of forest derived resources etc.) as it would assist in making recommendations and offer ways of mitigating against such problems.

An effective means of assessing change in forest cover, such as deforestation, is through utilising the capabilities of remote sensing and geographic information system (Htun et al., 2009, Phua et al., 2008, Curran et al., 2004, Giriraj et al., 2008, Liu et al., 2001). To assess and quantify changes over time, comparison against historical imagery are made using spectral and temporal characteristics of multi-temporal images (Armenteras et al., 2006, Onojeghuo and Blackburn, 2011). The collection of equivalent data through ground surveys could be time consuming and costly. Using remote sensing, maps showing changes in the forest cover over time and the spatial extent of these changes can be quantified. This study aimed to provide vital statistical data on the rates and spatial extent of forest transitional change (particularly deforestation) in the Okomu Forest Reserve.

The key objectives of the study were:

i. To determine the spatial extent and rates of deforestation, afforestation and forest change in the Okomu Forest Reserve using remotely sensed imagery over three different years(1987, 1999 and 2011); and

ii. To establish if the forest protected area status of the OFR has impacted positively or negatively on its conservation.

\section{Data and methods}

\subsection{Study area}

The Okomu Forest Reserve (OFR), situated in Edo state south western Nigeria $\left(6^{\circ} 10^{\prime}-6^{\circ}\right.$ $30^{\prime} \mathrm{N} ; 5^{\circ} 00^{\prime}-5^{\circ} 30^{\prime}$ E) contains the Okomu National Park (previously known as the Okomu Wildlife Sanctuary) (Figure 1). The forest reserve has an approximate area of 1,120 square kilometres and is situated between rivers Osse and Siluko to the east and west respectively. The vegetation of the reserve is typical Guinea-Congo lowland rainforest and is characterized by a mosaic of swamp-forest, high forest, secondary forest, and open scrub (BirdLife International, 2011b). However, due to the existence of gaps created by intensified exploration of forests and occurrence of wind throws the extent of shrubs across the reserve has increased greatly (Ajayi, 2011). 

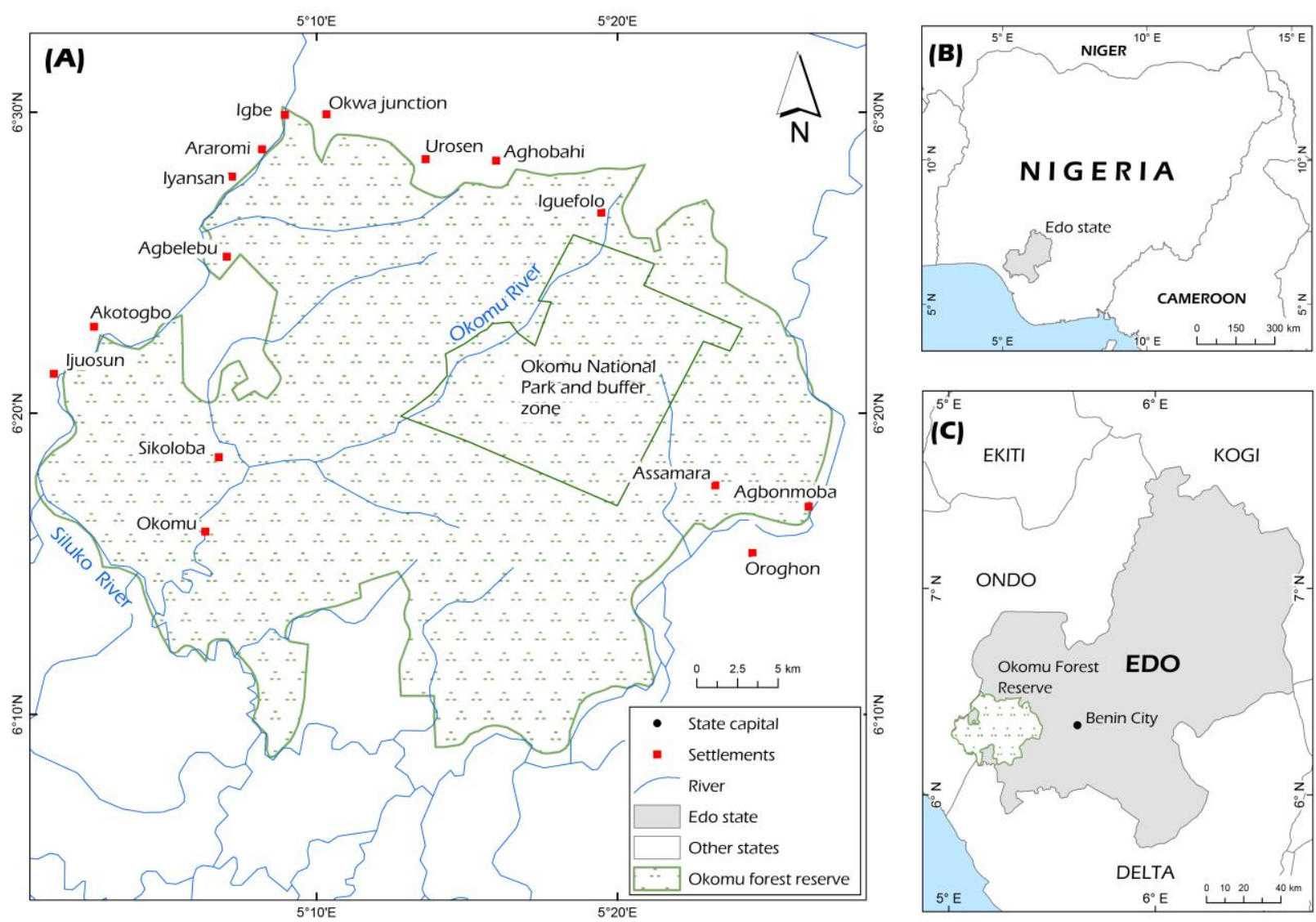

Figure 1: Map of study area showing (A): Okomu Forest Reserve and insert maps of (B):

Nigeria showing Edo state and (C) Edo state showing Okomu forest reserve.

\subsection{Data sources and image selection}

For this study, multi-temporal satellite images dated December 1987, December 1999 and January 2011 were used to perform forest cover classification and change detection analysis. After evaluating a wide range of satellite sensors suitable for land cover classification and change detection, the Landsat-5 Thematic Mapper (TM), Landsat-7 Enhanced Thematic Mapper Plus (ETM+) and United Kingdom - Disaster Monitoring and Constellation International Imaging (UK-DMC-2) Images were selected (Table 1). Since the UK-DMC-2 imagers are accurately calibrated to Landsat, it enables detailed comparison of imagery to identify changes in forest cover (http://www.dmcii.com/index.html). The Landsat images used were downloaded from United States Geological Survey (USGS) Earth Explorer website (http://earthexplorer.usgs.gov/) while the UK-DMC-2 satellite image was supplied by the Nigeria Space Agency, NASRDA (National Space Research and Development Agency) as a contribution to the study. The Landsat 5 and Landsat 7 ETM+ images covering the study area were of Worldwide Reference System 2 (WRS-2) path 190 and row 56. Table 1 summaries the characteristics of the satellite images used for the study. Table 1 summaries the characteristics of the satellite images used for the study. 
During the selection process, it was important that the satellite scenes contained minimal cloud cover or were totally free of such and acquired within the same season (as was the case in this study) to ensure uniformity. The satellite images used in this study were acquired during the dry season (which spans from October to April each year). The selection of satellite images in the same season allows for comparability of vegetation phenology and minimises discrepancies in reflectance caused by seasonal variation in vegetation and water regime, as well as sun angle differences (Coppin et al. 2004, Malingreau et al., 1995).

Table 1. Characteristics of satellite imagery used for the study

\begin{tabular}{|c|c|c|c|c|c|}
\hline $\begin{array}{l}\text { Satellite } \\
\text { Sensor }\end{array}$ & Date & $\begin{array}{l}\text { Spatial } \\
\text { Coverage } \\
(\mathbf{k m})\end{array}$ & $\begin{array}{l}\text { Spatial } \\
\text { Resolution } \\
(\mathrm{m})\end{array}$ & $\begin{array}{l}\text { Spectral } \\
\text { channel / band } \\
\text { number }\end{array}$ & $\begin{array}{l}\text { Comparable } \\
\text { Landsat (TM/ } \\
\text { ETM+) \& UK-DMC- } \\
2 \text { spectral bands / } \\
\text { bandwidth }(\mu \mathrm{m})\end{array}$ \\
\hline Landsat $5 \mathrm{TM}$ & $21-12-1987$ & $183 \times 185$ & 30 & \multirow{3}{*}{$\begin{array}{l}\text { Green (2), red ( } 3) \text { and } \\
\text { near-infrared (4) }\end{array}$} & B4 $(0.76-0.90)$ \\
\hline \multirow[t]{2}{*}{ Landsat 7 ETM+ } & \multirow[t]{2}{*}{ 13-12-1999 } & \multirow[t]{2}{*}{$194 \times 184$} & \multirow[t]{2}{*}{30} & & B3 $(0.63-0.69)$ \\
\hline & & & & & $\mathrm{B} 2(0.52-0.60)$ \\
\hline \multirow[t]{3}{*}{ UK-DMC 2} & \multirow[t]{3}{*}{ 18-01-2011 } & \multirow[t]{3}{*}{$393 \times 400$} & \multirow[t]{3}{*}{22} & \multirow{3}{*}{$\begin{array}{l}\text { Near-infrared (1), red } \\
\text { (2) and green ( } 3)\end{array}$} & $\mathrm{B} 1(0.77-0.90)$ \\
\hline & & & & & $\mathrm{B} 2(0.63-0.69)$ \\
\hline & & & & & $\mathrm{B} 3(0.52-0.60)$ \\
\hline
\end{tabular}

\subsection{Pre-processing of Landsat and UK-DMC-2 satellite images}

The key stages of image pre-processing undertaken in this study included geometric correction and validation, sub-setting of scenes to cover study area, radiometric calibration, atmospheric correction and pixel resampling. The Landsat and UK-DMC-2 images were level-1 products, indicating these were corrected for geometric accuracy using ground control points and digital elevation model (DEM). However, it is important to note that the accuracy achieved is dependent on the quality of control points and the resolution of the DEM used in the geo-rectification process. To ensure the satellite images were geometrically correct, all images were compared with a verified geometrically corrected satellite image of the study area. The process of geometric mis-alignment checks were performed using the polynomial geometric model of ERDAS Imagine (ERDAS, 2014). In order to maximise every spectral information contained in the satellite images, all forms of atmospheric effects caused by scattering and absorption from the earth surface radiation as at the time of acquisition was performed (Lu et al., 2000).

Before image classification and change detection analysis, all forms of noise contained in the Landsat and UK-DMC-2 satellite images were removed by converting the raw digital numbers (DN) to at-reflectance values. The noise sources were instrumental errors, changes 
in views and illumination and atmospheric effects were eliminated (Huang et al., 2002, Iqual, 2012). The calculations were based on equations (1) to (3) below:

$$
\begin{aligned}
& L_{\lambda}=\left(\text { DN }_{\lambda} * \text { Gain }_{\lambda}\right)+\text { Bias }_{\lambda} \\
& L_{\mu}=\left(\frac{D N_{\mu}}{\text { Gain }_{\mu}}\right)+\text { Bias }_{\mu} \\
& \rho_{\lambda / \mu}=\frac{\pi * L_{\lambda / \mu} * d^{2}}{E S U N_{\lambda / \mu} * \operatorname{Sin} \theta_{s e}}
\end{aligned}
$$

where $\mathrm{L}_{\lambda / \mu}=$ Spectral radiance at aperture of Landsat \& UK-DMC-2 sensor [W / (m2 sr $\mu \mathrm{m})$ ]; DN $\lambda / \mu=$ Digital number values of Landsat and UK-DMC-2 images; Gain $\lambda / \mu=$ gain values of specific bands in the image header files Landsat \& UK-DMC-2 images; Bias $\lambda / \mu=$ gain values for specific bands in the image header files; $\pi=3.14159 ; \mathrm{d}=$ Earth-Sun distance [astronomical distance]; ESUN $\lambda / \mu=$ Mean exoatmospheric solar irradiance [W / (m2 $\mu \mathrm{m})$ ]; $\theta_{\text {se }}=$ Solar / Sun elevation angle (degrees) (Huang et al., 2002, Iqual, 2012). It's important to state here that the cosine of solar zenith is the same as the sine of solar elevation. The value of solar elevation is provided in the metadata file that comes with the downloaded Landsat image and accompanied with the UK-DMC-2 satellite images.

After applying image pre-processing procedures (i.e. geometric correction, atmospheric correction, radiometric calibration and image sub-setting), all bands of UK-DMC-2 image was resampled to pixel size of 30 metres. All the images were subsequently used for ISODATA image classification and change detection analysis (Figure 2).

\subsection{Image classification and change detection analysis}

In this study, the unsupervised Iterative Self Organising Data Analysis (ISODATA) technique was used to classify the satellite images (Ball, 1965). The ISODATA classifier technique has shown to increase the accuracy of tropical forest land use mapping (Razali et al., 2014). The ISODATA classification technique uses minimum spectral distance formula to form clusters. The operation is based on either an arbitrary cluster of means or means of existing signature sets (ERDAS, 2014). The ISODATA classifier used in this study had 25 classes, confidence threshold of 0.99 and 250 maximum iterations. The land cover classes were categorised into six major classes namely forest, cropland, grassland, wetlands, settlements and other land classes. This classification scheme was based on the Intergovernmental Panel on Climate Change land use classification scheme (Smith et al., 2014) which reflected the land cover of the study area. In order to determine the spatial extent 
of forest cover change, the classified images were recoded to two distinctive classes, namely Forest and Non forest.

The process of image classification and accuracy assessment was performed using independendent training and testing data. The source of data used for deriving both training and testing data included historic reference data, existing topographic sheets, Google Earth, global positioning system (GPS) data and visual interpretation of the images during image classification. The accuracy assessment of the forest maps was performed using the Accuracy Assessment command in ERDAS Imagine (ERDAS, 2014).

The dynamics of forest transition was performed using Land Change Modeler (LCM) for ecological sustainability developed by IDRISI Selva (IDRISI, 2014). The LCM tools used forest maps of 1987, 1999 and 2011 to analyse changes in the forest landscape over two periods, namely period 1 (1987 - 1999) and period 2 (1999 - 2011) (Singh, 1989). The generated forest transition maps showed forest landscape deforested, unchanged and afforested for both periods. The annual deforestation rates of both periods were calculated using the forest landscape and forest transition map outputs.

\subsection{Dynamics of forest spatial and temporal transition within and surrounding OFR}

Using ArcGIS software (ESRI, 2014), buffer zones at $1 \mathrm{~km}$ intervals from the reserve boundary in both directions (i.e. inner and outer buffer zones) were generated. The adoption of the $3 \mathrm{~km}$ outside the forest reserve was arbitrarily used as there was no general consensus on what constitutes the surrounding area of the reserve (Phua et al. 2008). Studies show that comparing landscapes within and outside PAs have potential biases in assessing the effectiveness of PAs due to spatial heterogeneity between PAs and outside area (Mas, 2005). By restricting the surround area buffer zone to $3 \mathrm{~km}$, effects of topographic differences in landscape with the PA was reduced. For the study area, the land cover type, altitude and terrain type are similar to areas close to its boundary. The application of three consecutive inner and outer $1 \mathrm{~km}$ buffer zones would allow for more consistent physical variables between the first $1 \mathrm{~km}$ inner and outer buffer zones (Htun et al. 2009). 


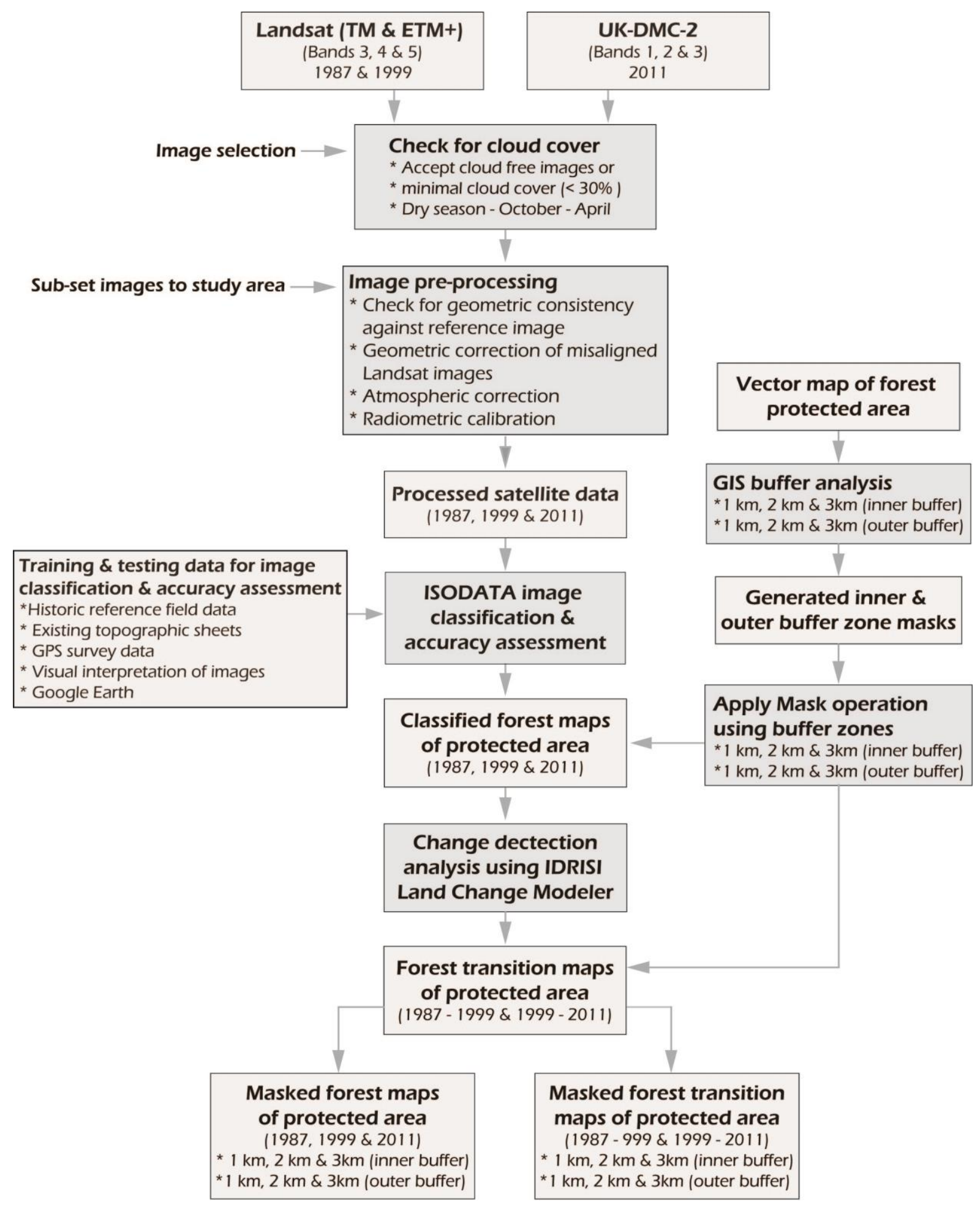

Figure 2. Methodology for remote sensing and GIS analysis. 


\section{Results}

\subsection{Accuracy assessment result}

Table 2 presents the accuracy assessment results of classified forest maps. The overall classification accuracy for 1987, 1999 and 2011 classified forest maps were 78\%, 84\% and $80 \%$.

Table 2. Error matrix of 1987, 1999 and 2011 classified forest maps for Okomu Forest Reserve.

\begin{tabular}{|c|c|c|c|c|}
\hline \multicolumn{5}{|l|}{ Forest map - 1987} \\
\hline Classified Data & Forest & Non forest & $\begin{array}{l}\text { Row } \\
\text { total }\end{array}$ & $\begin{array}{r}\text { Users } \\
\text { Accuracy }(\%) \\
\end{array}$ \\
\hline Forest & 43 & 13 & 56 & 76.8 \\
\hline Non forest & 10 & 40 & 50 & 80.0 \\
\hline Column Total & 53 & 53 & 106 & \\
\hline Producer's Accuracy (\%) & 81.1 & 75.5 & & \\
\hline Overall Accuracy (\%) & 78.3 & & & \\
\hline \multicolumn{5}{|l|}{ Forest map - 1999} \\
\hline Classified Data & Forest & Non forest & $\begin{array}{l}\text { Row } \\
\text { total }\end{array}$ & $\begin{array}{r}\text { Users } \\
\text { Accuracy }(\%)\end{array}$ \\
\hline Forest & 49 & 13 & 62 & 79.0 \\
\hline Non forest & 4 & 37 & 41 & 90.2 \\
\hline Column Total & 53 & 50 & 103 & \\
\hline Producer's Accuracy (\%) & 92.5 & 74.0 & & \\
\hline Overall Accuracy (\%) & 83.5 & & & \\
\hline \multicolumn{5}{|l|}{ Forest map - 2011} \\
\hline Classified Data & Forest & Non forest & Row & Users \\
\hline & & & total & Accuracy (\%) \\
\hline Forest & 50 & 18 & 68 & 73.5 \\
\hline Non forest & 3 & 32 & 35 & 91.4 \\
\hline Column Total & 53 & 50 & 103 & \\
\hline Producer's Accuracy (\%) & 94.3 & 64.0 & & \\
\hline Overall Accuracy $(\%)$ & 79.6 & & & \\
\hline
\end{tabular}

\subsection{Changes in forest landscape}

The forest cover maps clearly show a decline in the spatial coverage of forest landscape within OFR from 1987 to 2011 (Figure 3A, B and C). Over both 12 year periods, large extent of forest landscape was converted to non-forest area. Table 3 presents results of forest landscape area and changes from 1987 to 2011 . Approximately $80 \%$ of the total reserve was dominated by forest landscape (Table 4). In 1999, the total forest landscape declined from 89,560 hectare in 1987 to 50,571 hectares (a percentage loss of approximately $20 \%$ of the entire reserve). A similar trend of forest landscape decline was experienced in the second 12 year period for OFR. The forest landscape declined to 50,571 hectares which represented $45 \%$ of the entire reserve (Tables 3 and 4 ). 
In areas surrounding OFR, forest landscapes accounted for approximately $63 \%$ of the total landscape area in 1987. This decreased to about 55\% of the entire reserve in 1999 and slightly increased to $56.1 \%$ in 2011 (Table 4). The total area of unchanged forest landscape across OFR reduced from 57,325 hectares in period 1 (1987 - 1999) to 32,277 hectares in period 2 (1999 - 2011) (Table 3). The total area of afforested landscape in OFR increased from 9,361 hectares in period 1 to 18,294 hectares in period 2 (Table 3).
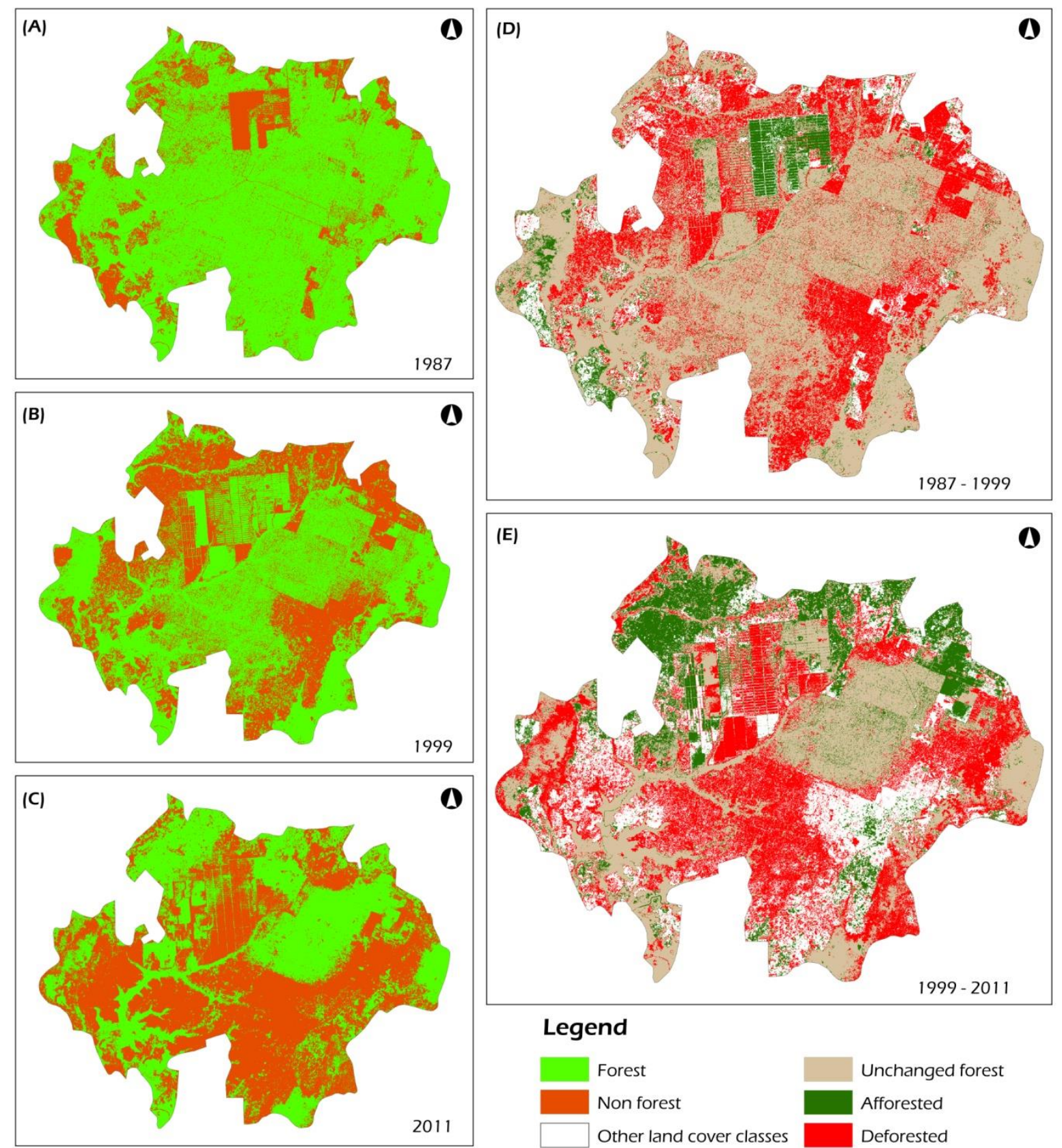

(
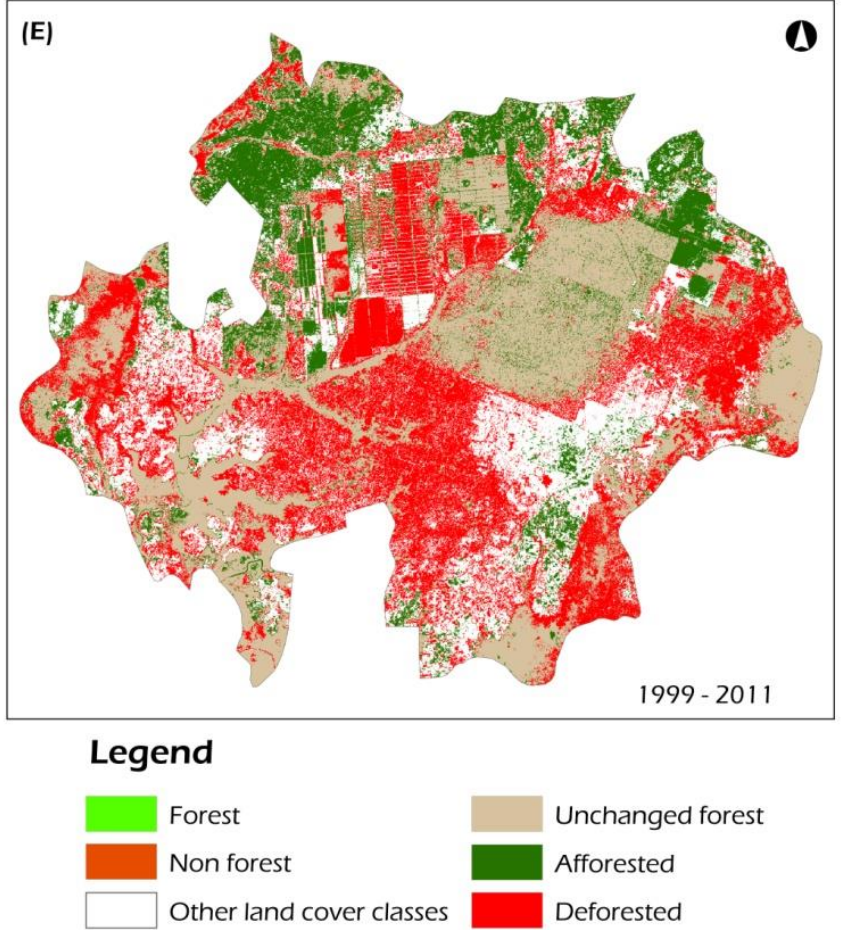

Figure 3. Forest cover maps for (A) 1987; (B) 1999; (C) 2011 and forest transition maps for two periods (D) period $1-1987$ to 1999 and (E) period 2-1999 to 2011 for Okomu forest reserve. 
Table 3 Spatial extent and transition (deforested, unchanged and afforested) of forest landscape within and outside study area from 1987 to 2011

\begin{tabular}{|c|c|c|c|c|c|c|c|c|c|c|}
\hline \multirow[t]{2}{*}{ Sites } & \multicolumn{3}{|c|}{ Forest landscape area } & \multicolumn{2}{|c|}{ Deforested (ha) } & \multicolumn{2}{|c|}{ Unchanged (ha) } & \multicolumn{2}{|c|}{ Afforested (ha) } & \multirow{2}{*}{$\begin{array}{c}\text { Total landscape } \\
\text { area (ha) }\end{array}$} \\
\hline & 1987 & 1999 & 2011 & $87-99$ & $99-11$ & $87-99$ & $99-11$ & $87-99$ & $99-11$ & \\
\hline Okomu FR & $89,560.3$ & $66,685.9$ & $50,571.1$ & $32,235.1$ & $34,408.5$ & $57,325.2$ & $32,277.4$ & $9,360.7$ & $18,293.7$ & $112,016.9$ \\
\hline $2 \mathrm{~km}$ outer buffer & $12,466.4$ & $11,396.3$ & $10,748.7$ & $3,595.1$ & $5,592.9$ & $8,871.2$ & $5,803.5$ & $2,525.1$ & $4,945.2$ & $19,956.7$ \\
\hline $3 \mathrm{~km}$ outer buffer & $11,171.6$ & 9,836 & $10,428.7$ & $3,595.6$ & $4,393.2$ & $7,576.0$ & $5,442.8$ & $2,260.0$ & $4,985.8$ & $18,465.2$ \\
\hline $3 \mathrm{~km}$ inner buffer & $11,980.6$ & $8,389.5$ & $7,046.6$ & $4,901.6$ & $4,532.5$ & $7,063.1$ & $3,847.9$ & $1,317.2$ & $3,189.7$ & $14,712.7$ \\
\hline
\end{tabular}

Table 4 Percentage of forest landscape and annual deforestation rates within and outside Okomu Forest Reserve from 1987 to 2011

\begin{tabular}{llllllcr}
\hline \multirow{2}{*}{ Sites } & \multicolumn{2}{c}{ Percentage of forest landscape (\%) } & & \multicolumn{2}{c}{ Annual deforestation rate (\%) } \\
\cline { 2 - 3 } \cline { 6 - 7 } & $\mathbf{1 9 8 7}$ & $\mathbf{1 9 9 9}$ & $\mathbf{2 0 1 1}$ & & $\mathbf{1 9 8 7 - 1 9 9 9}$ & $\mathbf{1 9 9 9 - 2 0 1 1}$ \\
\hline Okomu FR & 80.0 & 59.5 & 45.1 & & 3.5 & 5.1 \\
$1 \mathrm{~km}$ outer buffer & 64.6 & 53.6 & 57.7 & & 2.6 & 1.7 \\
$2 \mathrm{~km}$ outer buffer & 62.5 & 57.1 & 53.9 & & 1.7 & 2.9 \\
$3 \mathrm{~km}$ outer buffer & 60.5 & 53.3 & 56.5 & & 2.1 & 3.9 \\
$1 \mathrm{~km}$ inner buffer & 74.7 & 55.6 & 55.1 & & 3.5 & 2.2 \\
$2 \mathrm{~km}$ inner buffer & 79.2 & 57.1 & 50.9 & & 3.9 & 3.5 \\
$3 \mathrm{~km}$ inner buffer & 81.4 & 57.0 & 47.9 & & 4.5 & 4.4 \\
\hline
\end{tabular}




\subsection{Deforestation}

The total extent of deforested landscape within OFR for the two periods considered was 32,235 hectares between 1987 and 1999 and 34,409 hectares between 1999 and 2011 (Table 3). Between both 12-year periods, the annual deforestation rates for OFR increased from $3.5 \%$ to $5.1 \%$ (Table 4). In the surrounding area, annual deforestation rate increased noticeably between 1987-1999 and 1999-2011 within the $2 \mathrm{~km}$ buffer zone (Figure 4A). The annual deforestation rate in the first $1 \mathrm{~km}$ outer buffer zone declined between period 1 and period 2, a similar pattern of decline in the first $1 \mathrm{~km}$ inner buffer zone. In the $3 \mathrm{~km}$ outer buffer, annual deforestation rate declined between 1987 1999 and 1999-2011. The results further indicated that percentages of deforested landscape across all intervals of the outer buffer zones consistently increased over time and distance (Figure 4B).

Inside OFR, the annual deforestation rates for period $1(1987$ - 1999) and period $2(1999-2011)$ were lowest in the first $1 \mathrm{~km}$ buffer and highest in the $3 \mathrm{~km}$ buffer (Figure $4 \mathrm{~B}$ ). The $3 \mathrm{~km}$ buffer zone in period 1 had the highest overall annual deforestation rate across the inner buffer zone, affecting approximately $33 \%$ of its total landscape (Figure 4A).
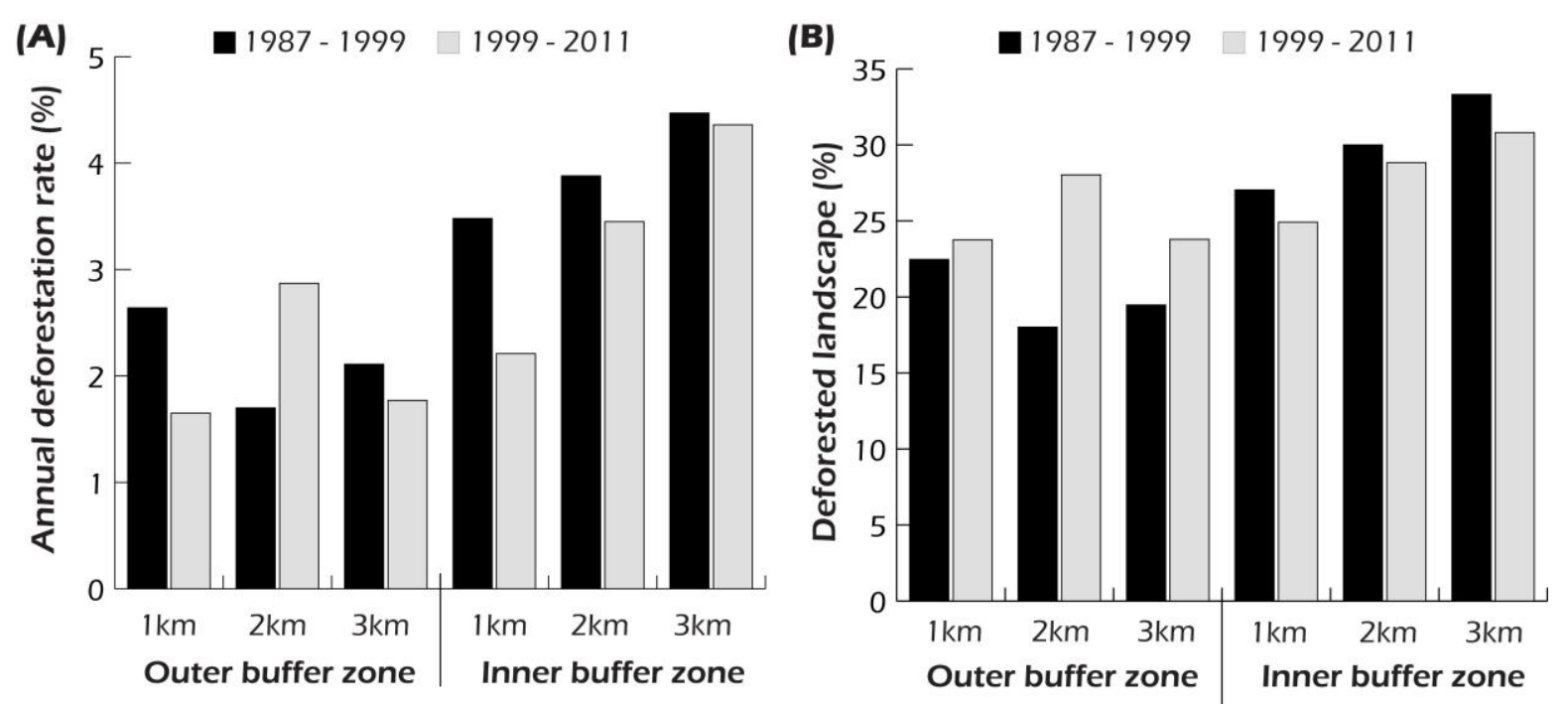

Figure 4 (A) Annual deforestation rates and (B) Percentage of deforested landscape area for outer and inner buffer zones from 1987 to 2011

\section{Discussion}

In this study, the integration of multi-temporal image classification with GIS has revealed forest landscape changes in OFR and its surrounding. The area of deforested landscape increased between 1987-1999 and 1999-2011 within the reserve. The annual rates of deforestation within OFR for both 12-year periods were higher than outside the reserve. The high rates of deforestation are attributed to intensified agricultural activities (mostly subsistence and plantation), over exploitation of the forest resources due to rising population (Osehobo, 2013) and bush burning. The results are consistent with recent studies and report (Anadu et al. 1988, Eguavoen, 2007, Osehobo, 2013). Osehobo (2013) reported that Okomu National Park, situated in OFR, is under immense threat from large scale illegal logging, rapid expansion of oil palm plantations and incursion of a growing human population involved in farming and hunting. The pressure of rapid plantation expansion is 
demonstrated in the south east part of the reserve, which is dominated by large rubber and oil palm plantation (Figure 3D and 3E). The overall results of this study show that forest protected status assigned to OFR has not effectively assisted in combating deforestation over the 24-year period investigated. Studies have indicated that formally approved protected areas are less prone to deforestation (Mas, 2005, Sánchez-Azofeifa et al., 2003, DeFries et al. 2005). However, results of this study further demonstrate the need to review reserve management policy and encourage forest conservation programmes within the study area. The implementation of reforestation programmes aimed at enhancing the enrichment and natural regeneration process of forest landscapes is highly encouraged. Though these measures are currently in place within OFR as indicated by Ajayi (2011), implementation and enforcement are generally lacking. We therefore recommend an active participation of government, reserve managers and local community in combating threats of deforestation affecting the reserve.

\section{Conclusion}

Based on the results generated, forest protected status assigned OFR has not fully mitigated against the effects of deforestation within and around the reserve. Though the afforestation rates over both 12-year periods investigated (i.e. period 1 and 2 respectively) increased from $1.6 \%$ to $2.6 \%$, the corresponding spatial coverage of afforested landscape was insignificant compared to the areas deforested. With this back drop, there's urgent need for the State and Federal Government authorities charged with the responsibility of managing protected areas to review existing forest policies and ensure the protection and conservation of existing forest protect areas and dependent wildlife. Asides, from the role of government, there is an urgent need for forest managers and conservation organisations involved in daily management of the reserve to improve on their methods / approach to conservation. The forest landscape on the fringes and within OFR are under immense pressure from diverse anthropogenic factors such as uncontrolled bush burning, illegal logging activities and indiscriminate farming by surrounding communities. There is an urgent need for the state and federal government, non-governmental conservation organisations and other stakeholders to work closely with local communities in the area to jointly combat the rising threats to this fragile forest reserve. The importance of protected areas conservation is critical in combating the threats of deforestation across the world. It's therefore, important that emphasis on forest conservation be heightened across Nigeria and Africa at large. This study has demonstrated the usefulness of using remote sensing and geographic information system in better understanding the dynamics of forest cover transition in an ecologically important forest protected area in Nigeria.

\section{Acknowledgement}

The authors would like to appreciate the Nigeria Space Agency NASRDA (National Space Research and Development Agency) for making available the UK-DMC satellite data used for this study. 


\section{References}

Ajayi, S. S. 2011, Case study 2: Multipurpose forest management for bush meat production: a success story from West Africa, FAO, November, viewed 16 July 20155, http://www.fao.org/forestry/10258-c60dbb6d55b4eb656bacabf3808aa4a3.pdf>.

Anadu, P., Elamah, P. \& Oates, J. F. 1988, 'The bushmeat trade in southwestern Nigeria: a case study', Human Ecology, vol. 16, pp. 199-208.

Armenteras, D., Rudas, G., Rodriguez, N., Sua, S. \& Romero, M. 2006, 'Patterns and causes of deforestation in the Colombian Amazon', Ecological Indicators, vol. 6, pp. 353-368.

Ball, G.H., Hall, D.J., 1965, Isodata, a novel method of data analysis and pattern classification; DTIC Document.

Birdlife International. 2011a, Global IBA Criteria, viewed 27 June 2011, <http://www.birdlife.org/datazone/info/ibacritglob>.

Birdlife International. 2011b, Important Bird Areas factsheet: Okomu National Park, viewed 27 June 2011, <http://www.birdlife.org>.

Clark, S., Bolt, K. \& Campbell, A. 2008, 'Protected areas: an effective tool to reduce emissions from deforestation and forest degradation in developing countries?', UNEP-WCMC, Cambridge, UK.

Coppin, P., Jonckheere, I., Nackaerts, K., Muys, B. \& Lambin, E. 2004, 'Review ArticleDigital change detection methods in ecosystem monitoring: a review', International Journal of Remote Sensing, vol. 25, pp. 1565-1596.

Curran, L. M., Trigg, S. N., Mcdonald, A. K., Astiani, D., Hardiono, Y. M., Siregar, P., Caniago, I. \& Kasischke, E. 2004, 'Lowland forest loss in protected areas of Indonesian Borneo', Science, vol. 303, pp. 1000-1003.

DeFries, R., Hansen, A., Newton, A.C. Hansen, M.C. 2005, 'Increasing isolation of protected areas in tropical forests over the past twenty years,' Ecological Applications, vol. 15, pp. 19-26.

Dudley, N. 2008, Guidelines for applying protected area management categories, IUCN, Switzerland.

Eguavoen, E. O. 2007, Modelling land cover change in Edo and Delta states, Nigeria, University of Leicester, Department of Geography, viewed 01 August 2015, <https://lra.le.ac.uk/handle/2381/30417>.

ERDAS 2014, ERDAS Imagine 2014, Peachtree Corners Circle Norcross: Hexagon Geospatial.

ESRI. 2014, ArcGIS Desktop: Release 10.2, Redlands, CA: Environmental Systems Research Institute, <http:// www.esri.com>. 
Giriraj, A., Babar, S. \& Reddy, C. S. 2008, 'Monitoring of forest cover change in Pranahita Wildlife Sanctuary, Andhra Pradesh, India using remote sensing and GIS', Journal of Environmental Science and Technology, vol. 1, pp. 73-79.

Htun, N. Z., Mizoue, N., Kajisa, T. \& Yoshida, S. 2009, 'Deforestation and forest degradation as measures of Popa Mountain Park (Myanmar) effectiveness', Environmental Conservation, vol. 36, no. 3, pp. 218-224.

Huang, C., Wylie, B., Yang, L., Homer, C. \& Zylstra, G. 2002, 'Derivation of a tasselled cap transformation based on Landsat 7 at-satellite reflectance', International Journal of Remote Sensing, vol. 23, pp. 1741-1748.

IDRISI, 2014, Idris Selva Version 17, Clark Labs, Clark University: Worcester, United States of America.

Iqbal, M. 2012. An Introduction to Solar Radiation, Elsevier.

Jones, E. 1955, 'Ecological Studies on the Rain Forest of Southern Nigeria: IV. The Plateau Forest of the Okomu Forest Reserve', The Journal of Ecology, vol. 44, no. 1, pp. 564-594.

Liu, J., Linderman, M., Ouyang, Z., An, L., Yang, J. \& Zhang, H. 2001, 'Ecological degradation in protected areas: the case of Wolong Nature Reserve for giant pandas', Science, vol. 292, pp. 98-101.

Lu, D., Mausel, P., Brondizio, E. , 2000, 'Assessment of atmospheric correction methods applicable to Amazon Basin IBA research', International Journal of Remote Sensing, vol. 23, pp. 2651-2671.

Malingreau, J., Achard, F., D'souza, G., Stibig, H., D'souza, J., Estreguil, C. \& Eva, H. 1995, 'AVHRR for global tropical forest monitoring: The lessons of the TREES project', Remote Sensing Reviews, vol. 12, pp. 29-40.

Mas, J-F. 2005, 'Assessing protected area effectiveness using surrounding (buffer) areas environmentally similar to the target area. Environmental monitoring and assessment', vol. 105, pp. 69-80.

Oates, J. F. 1995, 'The dangers of conservation by rural development-a case-study from the forests of Nigeria', Oryx, vol. 29, pp. 115-122.

Onojeghuo, A. O. \& Blackburn, G. A. 2011, 'Forest transition in an ecologically important region: patterns and causes for landscape dynamics in the Niger Delta', Ecological Indicators, vol. 11, pp. 1437-1446.

Osehobo, V. 2013, Nature under threat, Otedo News Update, viewed 6 October 2015, <http://ihuanedo.ning.com/m/group/discussion?id=2971192\%3ATopic\%3A90943>. 
Phua, M.H., Tsuyuki, S., Furuya, N. \& Lee, J. S. 2008, 'Detecting deforestation with a spectral change detection approach using multitemporal Landsat data: A case study of Kinabalu Park, Sabah, Malaysia', Journal of Environmental Management, vol. 88, pp. 784-795.

Razali, S. M., Marin, A., Nuruddin, A. A., Shafri, H. Z. M. \& Hamid, H. A. 2014, 'Capability of Integrated MODIS Imagery and ALOS for Oil Palm, Rubber and Forest Areas Mapping in Tropical Forest Regions. Sensors', vol. 14, pp. 8259-8282.

Richards, P. W. 1939, 'Ecological studies on the rain forest of Southern Nigeria: I. The structure and floristic composition of the primary forest', The Journal of Ecology, pp. 1-61.

Sánchez-Azofeifa, G.A., Daily, G.C., Pfaff, A.S.P., Busch, C. 2003, 'Integrity and Isolation of Costa Rica's National Parks and Biological Reserves: Examining the Dynamics of LandCover Change,' Biological Conservation, vol. 109, pp. 123-135.

Singh, A. 1989, 'Review article digital change detection techniques using remotely-sensed data', International journal of remote sensing, vol. 10, pp. 989-1003.

Smith, P., Bustamante, M., Ahammad, H., Clark, H., Dong, H., Elsiddig, E. A., Haberl, H., Harper, R., House, J., Jafari, M., Masera, O., Mbow, C., Ravindranath, N. H., Rice, C. W., Robledo Abad, C., Romanovskaya, A., Sperling, F. \& Tubiello, F. 2014. Agriculture, Forestry And Other Land Use (Afolu). In: Edenhofer, O., R. Pichs-Madruga, Y. Sokona, E. Farahani, S. Kadner, K. Seyboth, A. Adler, I. Baum, S. Brunner, P. Eickemeier, B. Kriemann, J. Savolainen, S. Schlömer, C. Von Stechow, Zwickel, T. \& Minx, J. C. (eds.) Climate Change 2014: Mitigation of Climate Change. Contribution of Working Group III to the Fifth Assessment Report of the Intergovernmental Panel on Climate Change. Cambridge, United Kingdom and New York, NY, USA.: Cambridge University Press. pp 811 - 922.

White, L. \& Oates, J. 1999, 'New data on the history of the plateau forest of Okomu, southern Nigeria: an insight into how human disturbance has shaped the African rain forest', Global Ecology and biogeography, vol. 8, pp. 355-361. 